\title{
PENERAPAN TEKNIK MULSA VERTIKAL PADA LAHAN TERDEGRADASI DI CARITA, PROVINSI JAWA BARAT
}

\author{
(Application of Vertical Mulch Technique on Degraded Land at Carita, West Java \\ Province)
}

\author{
Pratiwi $^{1}$, Nina Mindawati ${ }^{1}$ dan/and Darwo $^{1}$ \\ ${ }^{1}$ Pusat Penelitian dan Pengembangan Hutan \\ Jl. Gunung Batu no.5 - PO BOX 165, Bogor, Jawa Barat, Indonesia \\ Telp: 0251-8633234, Fax 0251-8638111 \\ E-mail: pratiwi.lala@yahoo.com,ninapulp@yahoo.co.id, darwop3h@gmail.com
}

Tanggal diterima: 20 Desember 2017; Tanggal direvisi: 22 April 2019; Tanggal disetujui; 23 April 2019

\begin{abstract}
Degraded land in the Carita Research Forest, West Java is commonly found in slopes. As a result, erosion, runoff and nutrient loss often occur in this area. To address these problems, the application of soil and water conservation techniques with a vertical mulch technique is required. The aim of the study was to determine the effect of vertical mulch treatment on the amount of runoff, erosion, nutrient loss and also its impact on the growth of $\underline{S}$. johorensis, $\underline{G}$. gnemon, and $\underline{P}$. speciosa. The results showed that soil and water conservation techniques with vertical mulch are very effective in reducing runoff, erosion and nutrient losses (N, $P, K, C a$ and $M g$ ). The vertical mulch of mixed planting pattern between $\underline{S}$. johorensis and $\underline{G}$. gnemon could decrease the surface run off and erosion by $61.74 \%$ and $57.14 \%$, respectively, while the mixture of $\underline{S}$. johorensis and $\underline{P}$. speciosa decreased the runoff and erosion rate equal to $81.39 \%$ and $17.64 \%$, respectively. In addition, the use of vertical mulch could also increase the growth of the tree species until the age of 3 years in the field compared to those without treatment.
\end{abstract}

Keywords: Vertical mulch technique, degraded land, Carita Reseach Forest

\begin{abstract}
ABSTRAK
Lahan terdegradasi banyak dijumpai di Hutan Penelitian Carita, Jawa Barat, khususnya di lahan-lahan berlereng. Akibatnya seringkali terjadi erosi, aliran permukaan dan hilangnya unsur hara. Untuk mengatasi hal tersebut perlu dilakukan penerapan teknik konservasi tanah dan air dengan teknik mulsa vertikal. Tujuan penelitian adalah mengetahui pengaruh perlakuan mulsa vertikal terhadap besarnya aliran permukaan, erosi dan kehilangan unsur hara serta dampaknya terhadap pertumbuhan tanaman S. johorensis, G. gnemon, dan P. speciosa. Hasil penelitian menunjukkan bahwa teknik konservasi tanah dan air dengan mulsa vertikal sangat efektif dalam mengurangi laju aliran permukaan, erosi dan kehilangan unsur hara (N, P, K, Ca dan Mg). Mulsa vertikal pada pola tanam campuran jenis S. johorensis dan G. gnemon, dapat menurunkan aliran permukaan dan erosi masing-masing 61,74\% dan 57,14\%; sedangkan campuran S. johorensis dan P. speciosa, menurunkan laju aliran permukaan dan erosi sebesar masing-masing 81,39\% dan 17,64\%. Selain itu, penggunaan mulsa vertikal juga dapat meningkatkan pertumbuhan ketiga jenis tanaman yang diusahakan sampai umur 3 tahun di lapangan dibanding tanpa penggunaan mulsa vertikal.
\end{abstract}

Kata kunci: Teknik mulsa vertikal, lahan terdegradasi, Hutan Penelitian Carita

\section{PENDAHULUAN}

Pengelolaan sumberdaya hutan tropis di Indonesia mengalami tantangan yang berat, dimana laju degradasi dan deforestrasi tidak seimbang dengan laju rehabilitasinya dari tahun ke tahun. Deforestrasi dalam skala besar menyebabkan penyusutan keanekaragaman hayati dan di banyak tempat menyebabkan erosi tanah, sedimentasi dan penghancuran fungsi hidrologis hutan sehingga mengancam potensi manfaat ekonomi dan lingkungan 
dari hutan untuk masa depan. Selain itu, kerusakan lahan hutan disebabkan pula oleh cepatnya alih fungsi hutan, tekanan penduduk yang perlu lahan, dampak perubahan iklim, pembalakan liar, kebakaran dan lain-lain. Hal ini menyebabkan sebagian besar lahan hutan menjadi rentan, terfragmentasi, daya dukung rendah dan tidak produktif atau marginal (Mindawati, 2016).

Luasnya lahan marginal yang tidak berhutan memerlukan upaya untuk menemukan teknologi yang dapat merehabilitasi lahan yang rusak tersebut. Rehabilitasi lahan merupakan suatu usaha memperbaiki, memulihkan kembali dan meningkatkan kondisi lahan yang rusak agar dapat berfungsi secara optimal baik sebagai unsur produksi, media pengatur tata air, maupun sebagai unsur perlindungan alam dan lingkungan.

Salah satu lahan yang termasuk lahan kritis atau marginal ada di Hutan Penelitian Carita dengan kondisi topografinya relatif curam dan berbukit pada ketinggian \pm 100 $\mathrm{m}$ dari muka laut (dpl). Kondisi lahan tersebut telah terdegradasi karena adanya perambahan yang dilakukan oleh penduduk sekitar hutan untuk bercocok tanam. Hal ini menyebabkan meningkatnya lahan kritis, termasuk berkurangnya vegetasi asli sebagai penghasil kayu pertukangan yang digantikan dengan tanaman serbaguna dan tanaman semusim (Murniati, 2012). Akibatnya laju aliran permukaan, erosi dan kehilangan unsur hara meningkat di lahan tersebut.

Berdasarkan hasil pengamatan, jenis tanaman hutan yang potensial dikembangkan di daerah Carita dan bernilai ekonomi adalah jenis-jenis dari suku Dipterocarpaceae, seperti Shorea spp., Hopea spp., Dipterocarpus spp., dan Vatica spp. (Pusat Penelitian dan Pengembangan Hutan, 2015). Salah satu jenis pada genus Shorea yang berpotensi tinggi untuk dikembangkan sebagai tanaman kayu pertukangan adalah Shorea johorensis Foxw. karena mempunyai nilai ekonomi tinggi dan pada umur kurang dari 30 tahun diameternya bisa mencapai $50 \mathrm{~cm}$ (Soekotjo, 2009). Oleh karena itu, penelitian rehabilitasi dengan pola tanam campuran antara tanaman S. johorensis dengan jenis Gnetum gnemon Linn. dan Parkia speciosa Hassk. telah dilakukan di Hutan Penelitian Carita. Pola tersebut diharapkan dapat membantu peningkatan pendapatan masyarakat sekitar tanpa merusak ekosistem karena hasil yang dipanen dari G. gnemon dan P. speciosa bukan hanya kayu tetapi juga buahnya, bahkan pada G. gnemon daunnya juga biasa digunakan sebagai bahan sayuran oleh masyarakat setempat.

Selain itu, mengingat kondisi topografi daerah ini berbukit, maka perlu upaya konservasi tanah dan air untuk mengendalikan erosi dan aliran permukaan. Salah satu teknik konservasi tanah dan air yang dapat diterapkan adalah teknik mulsa vertikal. Teknik mulsa vertikal merupakan salah satu teknik konservasi tanah dan air melalui pemanfaatan limbah hutan (serasah) yang ada di sekitar dengan memasukannya ke dalam saluran atau alur yang dibuat sejajar kontur pada bidang yang diusahakan (Pratiwi \& Narendra, 2012). Teknik ini sudah banyak diterapkan di bidang pertanian di lahan-lahan berlereng. Namun demikian, di bidang kehutanan belum banyak diterapkan, sementara di lahan-lahan bekas tebangan, banyak dijumpai limbah hutan dalam bentuk serasah ataupun tumbuhan pengganggu (gulma). Teknik konservasi dengan mulsa vertikal dan cara rorak di dalam merehabilitasi lahan-lahan berlereng, dapat mengurangi laju aliran permukaan, erosi dan kehilangan unsur hara (Pratiwi \& Salim, 2013).

Sehubungan dengan hal tersebut di atas, maka penelitian ini bertujuan untuk mengetahui pengaruh perlakuan mulsa vertikal terhadap besarnya aliran permukaan, erosi dan kehilangan unsur hara serta dampaknya terhadap pertumbuhan tanaman S. johorensis, G. gnemon, dan P. speciosa. Diharapkan hasil penelitian ini bermanfaat bagi pengguna di lapangan. 


\section{METODOLOGI}

\section{A. Lokasi}

Penelitian dilakukan di Hutan Penelitian Carita, Jawa Barat. Daerah penelitian memiliki iklim A, dengan curah hujan $3.959 \mathrm{~mm} / \mathrm{tahun}$ dan jenis tanah alluvial kelabu tua. Topografi lokasi penelitian berbukit dengan lereng sekitar 55\% (Pusat Penelitian dan Pengembangan Hutan, 2015).

\section{B. Metode}

\section{Rancangan penelitian}

Penelitian ini menggunakan Rancangan Acak Kelompok. Pengelompokan dilakukan berdasarkan posisi kemiringan lahan yaitu lereng atas, tengah dan bawah. Perlakuan yang diberikan adalah:

$$
\begin{aligned}
& \mathrm{A}= \begin{array}{l}
\text { S. johorensis }+ \text { G. gnemon }+ \text { mulsa } \\
\text { vertikal }
\end{array} \\
& \mathrm{B}= \begin{array}{l}
\text { S. johorensis }+ \text { G. gnemon }+ \text { tanpa } \\
\text { mulsa }
\end{array} \\
& \mathrm{C}= \begin{array}{l}
\text { S. johorensis }+P . \text { specios } a+\text { mulsa } \\
\text { vertikal }
\end{array} \\
& \mathrm{D}=\begin{array}{l}
\text { S. johorensis }+P . \text { specios } a+\text { tanpa } \\
\text { mulsa }
\end{array}
\end{aligned}
$$

\section{Tahapan penelitian}

Tahapan penelitian dimulai dengan membuat plot berukuran $20 \times 20 \mathrm{~m}$. Masing-masing perlakuan dikelompokkan menjadi 3 kelompok. Dengan demikian, plot yang dibuat sebanyak 12 buah. Masing-masing plot ditanami dengan perlakuan yang telah ditentukan dengan jarak tanam $3 \times 3 \mathrm{~m}$. Setiap jalur tanam ditanam berselang-seling antara jenis yang satu dengan jenis lainnya. Selanjutnya mulsa vertikal diterapkan di dalam plot, dengan cara menggali saluran sedalam $60 \mathrm{~cm}$ sejajar garis kontur, panjang $20 \mathrm{~m}$ dengan lebar $30 \mathrm{~cm}$, jarak antar saluran $6 \mathrm{~m}$. Untuk mengamati aliran permukaan, erosi dan kehilangan unsur hara dipasang drum yang diletakkan di bagian hilir plot (Gambar 1).

Pengamatan yang dilakukan meliputi pertumbuhan tanaman, aliran permukaan, erosi dan kehilangan unsur hara. Pengu- kuran pertumbuhan tanaman dilakukan dengan cara mengukur tinggi dan diameter tanaman setiap tahun sekali selama 3 tahun. Pengamatan aliran permukaan dan erosi dilakukan setiap kejadian hujan. Data yang dicatat meliputi: jumlah curah hujan dan jumlah air yang masuk ke dalam drum. Contoh air diambil dari air yang tertampung di dalam bak. Pengukuran erosi dilakukan dengan metode evaporasi yaitu dengan menempatkan contoh air ke dalam cawan porselin dan dioven pada suhu $105^{\circ} \mathrm{C}$ selama 24 jam. Erosi dihitung dari sedimen yang tersisa dalam cawan tersebut. Contoh sedimen yang tertampung dalam drum dan contoh air limpasan yang masuk ke dalam bak selanjutnya dianalisis di laboratorium untuk menentukan besarnya kehilangan unsur hara (N, P, K, Ca, Mg, Na) akibat air limpasan dan erosi (Pratiwi \& Narendra, 2012). Selain itu, dalam penelitian ini dilakukan penghitungan biaya yang dikeluarkan untuk penerapan mulsa vertikal (Pratiwi \& Narendra, 2012).

\section{Analisis data}

Analisis keragaman (ANOVA) dilakukan untuk mengetahui pengaruh kelompok dan perlakuan terhadap pertumbuhan tanaman. Uji lanjut Tukey dilakukan, jika dalam analisis keragaman menunjukkan adanya pengaruh nyata dari perlakuan. Data erosi dan aliran permukaan serta kehilangan unsur hara dianalisis untuk mengetahui pengaruh antar perlakuan.

\section{HASIL DAN PEMBAHASAN}

\section{A. Hasil}

Teknik mulsa vertikal merupakan salah satu teknik konservasi tanah dan air yang dapat diterapkan di lahan berlereng. Teknik ini merupakan kombinasi antara pemanfaatan saluran dan guludan dengan mulsa. Pemanfaatan teknik ini diharapkan dapat mengurangi laju aliran permukaan, erosi dan kehilangan unsur hara, serta meningkatkan pertumbuhan tanaman. 


\section{Pengaruh mulsa vertikal terhadap} aliran permukaan, erosi dan kehilangan unsur hara

\section{a. Aliran permukaan dan erosi}

Berdasarkan hasil penelitian sebelumnya (Pratiwi, 2007) bahwa perlakuan mulsa vertikal pada pola tanam campuran mem-berikan besarnya aliran permukaan dan erosi seperti pada Tabel 1 .

Pada perlakuan A $(S$. johorensis $+G$. gnemon + mulsa vertikal) dan $\mathrm{C}(S$. johorensis $+P$. speciosa + mulsa vertikal) memberikan aliran permukaan dan erosi lebih rendah dibandingkan dengan plot kontrol $(\mathrm{B}=\mathrm{S}$. johorensis $+\mathrm{G}$. gnemon + tanpa mulsa; dan $\mathrm{D}=\mathrm{S}$. johorensis $+\mathrm{P}$. speciose + tanpa mulsa). Jika dibandingkan antar perlakuan $\mathrm{A}$ dan $\mathrm{C}$, maka aliran permukaan perlakuan A lebih besar daripada perlakuan $\mathrm{C}$, sedangkan erosinya lebih kecil.

\section{b. Kehilangan unsur hara}

Kehilangan unsur hara dapat terjadi melalui aliran permukaan maupun erosi. Kehilangan unsur hara melalui aliran permukaan terjadi karena unsur-unsur hara yang larut dalam air terbawa bersama air. Hasil yang lebih lengkap dapat dilihat di Tabel 2.

Tabel 2 menunjukkan bahwa unsurunsur hara yang hilang bersama aliran permukaan lebih kecil pada perlakuan mulsa vertikal dibandingkan tanpa mulsa. Unsur hara yang hilang bersama aliran permukaan yang terbesar adalah unsur $\mathrm{N}$, $\mathrm{K}$, dan Ca pada semua perlakuan.

Pada perlakuan $\mathrm{B}$ dan $\mathrm{D}$, kehilangan unsur hara $(\mathrm{N}, \mathrm{P}, \mathrm{K}, \mathrm{Ca}, \mathrm{Mg}, \mathrm{Na})$ tiga kali lebih besar jika dibandingkan dengan penerapan mulsa vertikal (A dan C). Kehilangan unsur hara pada perlakuan A lebih besar daripada perlakuan $\mathrm{C}$, terutama unsur hara $\mathrm{N}, \mathrm{K}$, dan $\mathrm{Ca}$.

Kehilangan unsur hara melalui erosi terjadi karena unsur-unsur hara tersebut terabsorpsi pada koloid tanah. Jika dibandingkan dengan unsur hara yang hilang bersama aliran permukaan, maka kehilangan unsur hara melalui erosi lebih kecil daripada melalui aliran permukaan (Tabel 3).

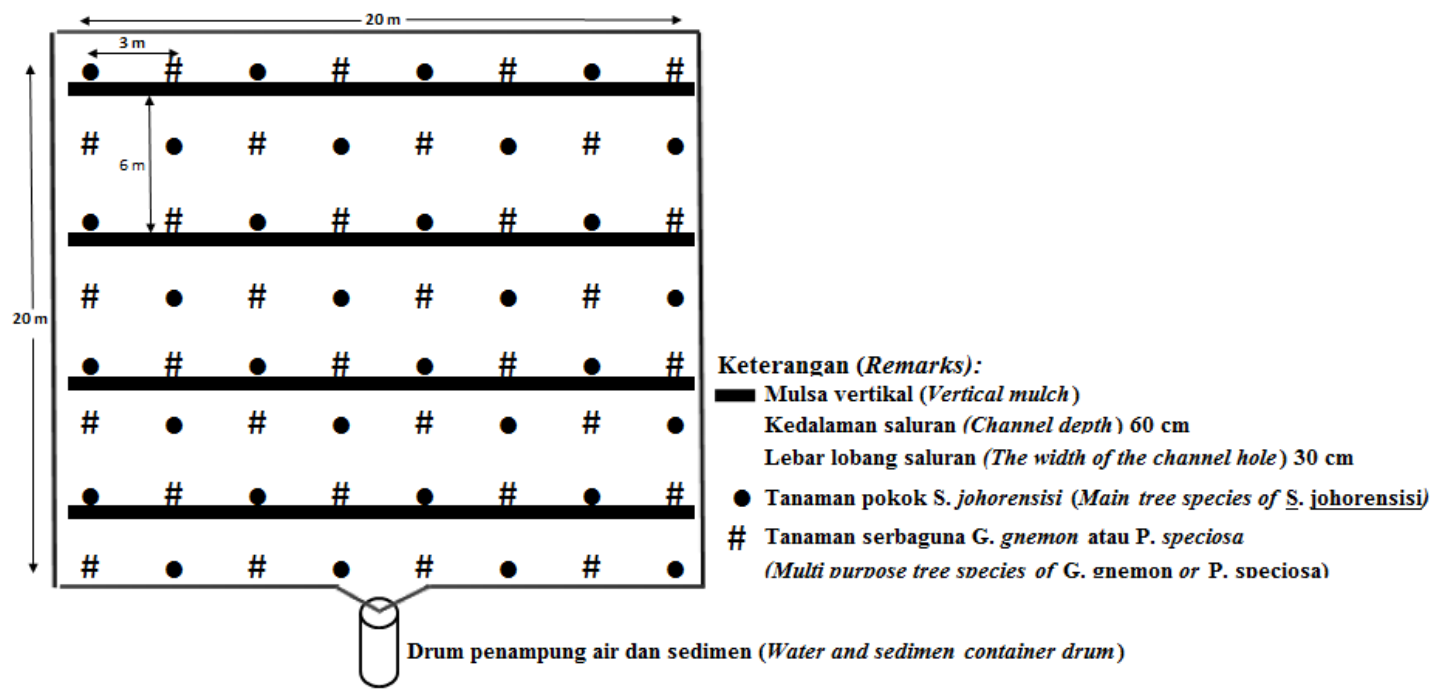

Gambar (Figure) 1. Sketsa pola tanam dan teknik mulsa vertikal (Sketch of cropping patterns and vertical mulch techniques) 


\section{Pengaruh mulsa vertikal terhadap pertumbuhan tanaman}

Dalam konservasi tanah dan air tidak hanya melihat aspek pengendalian erosi saja, tetapi perlu juga meninjau pengaruhnya terhadap obyek yang dikonservasi, seperti pertumbuhan tanaman. Hasil analisis ragam menunjukkan bahwa pola tanam berpengaruh nyata terhadap diameter dan tinggi $S$. johorensis pada umur 1, 2 dan 3 tahun setelah tanam, sedangkan terhadap pengelompokan tidak berpengaruh signifikan. Hasil pertumbuhan baik jenis $S$. johorensis maupun jenis $G$. gnemon dan $P$. speciosa dengan uji bedanya dapat dilihat pada Tabel 4 dan 5.

Dari hasil uji Tukey (Tabel 4) ternyata antar perlakuan pola tanam berbeda signifikan terhadap tinggi $\mathrm{S}$. johorensis pada umur 1 dan 2 tahun. Namun pada umur 3 tahun menunjukkan bahwa pola tanam A (S. johorensis $+\mathrm{G}$. gnemon + mulsa vertikal) masih konsisten berbeda signifikan dengan ketiga perlakuan tersebut, sedangkan antar pola tanam B (S. johorensis + G. gnemon + tanpa mulsa vertikal), C (S. johorensis + P. speciosa + mulsa vertikal) dan $\mathrm{D}$ (S. johorensis $+\mathrm{P}$. speciosa + mulsa vertikal) tidak berbeda nyata. Dengan demikian, jika S. johorensis ditanam dengan G. gnemon dan diberi mulsa vertikal merupakan perlakuan terbaik untuk pertumbuhan tinggi dan diameter.

Di pihak lain, Tabel 5 menunjukkan bahwa pada umur 1 dan 2 tahun, rata-rata tinggi G. gnemon pada pola tanam $S$. johorensis + G. gnemon + diberi mulsa vertikal lebih tinggi daripada tanpa pemberian mulsa dan berbeda signifikan. Namun pada umur 3 tahun tinggi $G$. gnemon yang diberi mulsa vertikal ternyata lebih tinggi daripada tanpa diberi mulsa vertikal. Pada umur 1 tahun, rata-rata diameter G. gnemon dengan dan tanpa mulsa vertikal relatif sama, sedangkan pada umur 2 dan 3 tahun lebih besar. Dengan demikian, perlakuan mulsa vertikal telah memberikan respon yang baik bagi pertumbuhan G. gnemon dan P. speciosa.

\section{Biaya yang diperlukan untuk menerapkan teknik mulsa vertikal}

Berdasarkan hasil perhitungan secara sederhana, biaya yang diperlukan dalam penerapan teknik mulsa vertikal adalah sebesar Rp 5.700.000 per hektar. Perincian biaya disajikan pada Tabel 6 .

Tabel (Table) 1. Besaran aliran permukaan dan erosi akibat perlakuan (The impact of treatments on runoff and erosion)

\begin{tabular}{llcc}
\hline No. & $\begin{array}{l}\text { Perlakuan } \\
\text { (Treatment) }\end{array}$ & $\begin{array}{c}\text { Aliran permukaan (Run off) } \\
(\mathrm{mm} / \text { ha/tahun) } \\
(\text { mm/ha/years })\end{array}$ & $\begin{array}{c}\text { Erosi (Erosion) } \\
\text { (ton/ha/tahun) } \\
(\text { ton/ha/years })\end{array}$ \\
\hline 1. & $\mathrm{~A}$ & 938 & 2,4 \\
2. & $\mathrm{~B}$ & 2.450 & 5,6 \\
3. & $\mathrm{C}$ & 326 & 4,2 \\
4. & $\mathrm{D}$ & 1.751 & 5,1 \\
\hline
\end{tabular}

Sumber (Source): (Pratiwi, 2007)

Keterangan (Remarks):

$\mathrm{A}=\mathrm{S}$. johorensis $+\mathrm{G}$. gnemon + mulsa vertikal $(\underline{S}$. johorensis $+\underline{G}$. gnemon + vertical mulch $)$

$\mathrm{B}=\mathrm{S}$. johorensis $+\mathrm{G}$. gnemon + tanpa mulsa $(\underline{S} . \underline{\text { johorensis }}+\underline{G}$. gnemon + no mulch $)$

$\mathrm{C}=\mathrm{S}$. johorensis $+\mathrm{P}$. speciosa + mulsa vertikal $(\underline{S}$. johorensis $+\underline{P} . \underline{\text { speciosa }}+$ vertical mulch $)$

$\mathrm{D}=\mathrm{S}$. johorensis + P. speciosa + tanpa mulsa $(\underline{S}$. johorensis $+\underline{P} . \underline{\text { speciosa }}+$ no mulch $)$ 
Tabel (Table) 2. Kehilangan unsur hara melalui aliran permukaan (Nutrient loss through runoff)

\begin{tabular}{ccccc}
\hline \multirow{2}{*}{$\begin{array}{l}\text { Unsur hara (Nutrient) } \\
(\text { (kg/ha/tahun) }\end{array}$} & \multicolumn{4}{c}{ Perlakuan (Treatment) } \\
\cline { 2 - 5 }$($ kg/ha/years $)$ & $\mathrm{A}$ & $\mathrm{B}$ & $\mathrm{C}$ & $\mathrm{D}$ \\
\hline $\mathrm{N}$ & 3,36 & 9,50 & 1,16 & 8,60 \\
$\mathrm{P}$ & 0,93 & 2,77 & 0,65 & 2,25 \\
$\mathrm{~K}$ & 1,06 & 4,74 & 0,55 & 3,75 \\
$\mathrm{Ca}$ & 2,25 & 7,37 & 0,63 & 6,70 \\
$\mathrm{Mg}$ & 0,37 & 0,93 & 0,13 & 0,84 \\
$\mathrm{Na}$ & 0,35 & 0,82 & 0,12 & 0,71 \\
\hline
\end{tabular}

Keterangan (Remarks):

$\mathrm{A}=\mathrm{S}$. johorensis + G. gnemon + mulsa vertikal $(\underline{S}$. johorensis $+\underline{G}$. gnemon + vertical mulch $)$

$\mathrm{B}=\mathrm{S}$. johorensis + G. gnemon + tanpa mulsa $(\underline{S}$. johorensis $+\underline{G}$. gnemon + no mulch $)$

$\mathrm{C}=\mathrm{S}$. johorensis + P. speciosa + mulsa vertikal $(\underline{S}$. johorensis $+\underline{P}$. speciosa + vertical mulch $)$

$\mathrm{D}=\mathrm{S}$. johorensis + P. speciosa + tanpa mulsa $(\underline{S}$. johorensis $+\underline{P} . \underline{\text { speciosa }}+$ no mulch $)$

Tabel (Table) 3. Kehilangan unsur hara melalui erosi (Nutrient loss through erosion)

\begin{tabular}{crrrr}
\hline $\begin{array}{l}\text { Unsur hara } \\
\text { (Nutrient }) \\
(\mathrm{kg} / \mathrm{ha} / \mathrm{tahun})\end{array}$ & \multicolumn{4}{c}{ Perlakuan (Treatment) } \\
\cline { 2 - 5 }$(\mathrm{kg} /$ ha/years $)$ & $\mathrm{A}$ & $\mathrm{B}$ & $\mathrm{C}$ & $\mathrm{D}$ \\
\hline $\mathrm{N}$ & 0,24 & 1,68 & 0,75 & 1,06 \\
$\mathrm{P}$ & 0,0001 & 0,0005 & 0,0002 & 0,0004 \\
$\mathrm{~K}$ & 0,15 & 0,44 & 0,23 & 0,44 \\
$\mathrm{Ca}$ & 0,17 & 0,68 & 0,37 & 0,61 \\
$\mathrm{Mg}$ & 0,12 & 0,48 & 0,18 & 0,58 \\
$\mathrm{Na}$ & 0,10 & 0,32 & 0,13 & 0,21
\end{tabular}

Keterangan (Remarks):

A $=$ S. johorensis + G. gnemon + mulsa vertikal $(\underline{S}$. johorensis $+\underline{G}$. gnemon + vertical mulch $)$

$\mathrm{B}=\mathrm{S}$. johorensis + G. gnemon + tanpa mulsa $(\underline{S}$. johorensis $+\underline{G}$. gnemon + no mulch $)$

$\mathrm{C}=\mathrm{S}$. johorensis + P. speciosa + mulsa vertikal $(\underline{S}$. johorensis $+\underline{P} . \underline{\text { speciosa }}+$ vertical mulch $)$

$\mathrm{D}=\mathrm{S}$. johorensis + P. speciosa + tanpa mulsa $(\underline{S}$. johorensis $+\underline{P}$. speciosa + no mulch $)$

Tabel (Table) 4. Rata-rata tinggi dan diameter S. johorensis pada umur 1, 2 dan 3 tahun (Average height and diameter of $\underline{S}$.johorensis at 1, 2 and 3 years old)

\begin{tabular}{|c|c|c|c|c|c|c|}
\hline \multirow{2}{*}{$\begin{array}{l}\text { Perlakuan/ } \\
\text { Treatment }\end{array}$} & \multicolumn{3}{|c|}{ Tinggi $($ Height $)(\mathrm{cm})$} & \multicolumn{3}{|c|}{ Diameter (mm) } \\
\hline & $\begin{array}{l}1 \text { tahun }(1 \\
\text { year) }\end{array}$ & $\begin{array}{l}2 \text { tahun } \\
(2 \text { years })\end{array}$ & $\begin{array}{c}3 \text { tahun }(3 \\
\text { years })\end{array}$ & $\begin{array}{l}1 \text { tahun } \\
(1 \text { year })\end{array}$ & $\begin{array}{l}2 \text { tahun } \\
(2 \text { years })\end{array}$ & $\begin{array}{c}3 \text { tahun }(3 \\
\text { years })\end{array}$ \\
\hline $\begin{array}{l}\text { S. johorensis + G.gnemon + mulsa } \\
\text { vertikal/vertical mulch (A) }\end{array}$ & 65,65 a & $105,28 \mathrm{a}$ & 120,31 a & $5,21 \mathrm{~b}$ & $9,50 \mathrm{a}$ & $13,13 \mathrm{a}$ \\
\hline $\begin{array}{l}\text { S. johorensis + G. gnemon + tanpa } \\
\text { mulsa/no mulch (B) }\end{array}$ & $47,29 \mathrm{~d}$ & $77,37 \mathrm{~d}$ & $103,41 \mathrm{~b}$ & $4,57 \mathrm{c}$ & $6,46 \mathrm{c}$ & $8,64 \mathrm{c}$ \\
\hline $\begin{array}{l}\text { S. johorensis + P. speciosa + mulsa } \\
\text { vertikal/vertical mulch }(\mathrm{C}) \\
\text { S. johorensis + P. speciosa }+ \text { tanpa }\end{array}$ & $63,35 \mathrm{~b}$ & $103,44 \mathrm{~b}$ & $105,69 \mathrm{~b}$ & $5,34 \mathrm{ba}$ & $9,31 \mathrm{a}$ & $11,31 \mathrm{~b}$ \\
\hline $\begin{array}{l}\text { S. Johorensls }+ \text { P. speciosa }+ \text { tanpa } \\
\text { mulsa vertikal/vertical mulch (D) }\end{array}$ & $60,68 \mathrm{c}$ & $99,11 \mathrm{c}$ & $102,21 \mathrm{~b}$ & $5,47 \mathrm{a}$ & $8,23 \mathrm{~b}$ & $9,08 \mathrm{c}$ \\
\hline
\end{tabular}

Keterangan (Remarks): Angka yang diikuti huruf yang sama pada kolom yang sama menunjukkan tidak berbeda nyata pada tingkat kepercayaan $95 \%$ (The numbers that are followed by the same letter indicated no significant differences at $95 \%$ level) 
Tabel (Table) 5. Rata-rata tinggi dan diameter G. gnemon dan P. speciosa pada umur 1, 2, dan 3 tahun (Average height and diameter of $\underline{G}$. gnemon and $\underline{P}$. speciosa at 1,2 , and 3 years old)

\begin{tabular}{|c|c|c|c|c|c|c|}
\hline \multirow[b]{2}{*}{ Perlakuan (Treament) } & \multicolumn{3}{|c|}{ Tinggi $($ Height $)(\mathrm{cm})$} & \multicolumn{3}{|c|}{ Diameter (mm) } \\
\hline & $\begin{array}{c}1 \text { tahun }(1 \\
\text { year })\end{array}$ & $\begin{array}{l}2 \text { tahun }(2 \\
\text { years })\end{array}$ & $\begin{array}{l}3 \text { tahun }(3 \\
\text { years })\end{array}$ & $\begin{array}{c}1 \text { tahun }(1 \\
\text { year })\end{array}$ & $\begin{array}{c}2 \text { tahun }(2 \\
\text { years })\end{array}$ & $\begin{array}{l}3 \text { tahun }(3 \\
\text { years })\end{array}$ \\
\hline $\begin{array}{l}\text { G. gnemon }(\mathbf{G} \text {. gnemon): } \\
\text { S. johorensis }+ \text { G. gnemon }+ \text { mulsa } \\
\text { vertikal (A) }\end{array}$ & $37,61 \mathrm{~b}$ & $67,97 \mathrm{~b}$ & 88,89 a & $3,53 \mathrm{a}$ & $7,54 a$ & $9,78 \mathrm{a}$ \\
\hline $\begin{array}{l}\text { S. johorensis }+ \text { G. gnemon }+ \text { tanpa } \\
\text { mulsa (B) }\end{array}$ & $40,70 \mathrm{a}$ & 77,33 a & $73,22 \mathrm{~b}$ & $3,61 \mathrm{a}$ & $4,50 \mathrm{~b}$ & $6,11 \mathrm{~b}$ \\
\hline $\begin{array}{l}\text { P. speciosa }(\mathbf{P} . \text { speciosa }): \\
\text { S. johorensis }+\frac{\text { P. speciosa }}{\text { vertikal }(\mathrm{C})}\end{array}$ & $44,42 \mathrm{a}$ & 102,26 a & $111,43 \mathrm{a}$ & $5,13 \mathrm{a}$ & $9,55 \mathrm{a}$ & a $10,30 \mathrm{a}$ \\
\hline $\begin{array}{l}\text { S. johorensis }+ \text { P. speciosa }+ \text { tanpa } \\
\text { mulsa vertikal (D) }\end{array}$ & $40,23 \mathrm{~b}$ & $90,78 \mathrm{~b}$ & $96,17 \mathrm{~b}$ & $4,13 \mathrm{~b}$ & $7,11 \mathrm{~b}$ & $8,29 \mathrm{~b}$ \\
\hline
\end{tabular}

Keterangan (Remarks): Angka yang diikuti huruf yang sama pada kolom yang sama menunjukkan tidak berbeda nyata pada tingkat kepercayaan $95 \%$ (The numbers that are followed by the same letter indicated no significant differences at $95 \%$ level)

\section{B. Pembahasan}

Mulsa vertikal merupakan salah satu teknik konservasi tanah dan air melalui pembuatan saluran yang dikombinasikan dengan guludan dan ke dalam saluran tersebut diisi mulsa. Teknik ini di bidang kehutanan belum banyak dimanfaatkan, sementara lahan-lahan miring dan terdegradasi di areal bekas tebangan maupun di dalam kawasan hutan banyak dijumpai. Lahan terdegradasi muncul disebabkan antara lain karena adanya perambahan oleh masyarakat sekitar hutan, seperti yang terjadi di Hutan Penelitian Carita. Teknologi konservasi tanah dan air untuk lahan-lahan miring seperti teknik mulsa vertikal diharapkan dapat mengurangi laju aliran permukaan, erosi dan kehilangan unsur hara. Menurut Harijanto, Sinukaban, Tarigan, \& Haridjaja (2016) bahwa erosi merupakan salah satu faktor yang mengakibatkan terjadinya penurunan kesuburan tanah, mengganggu pertumbuhan dan menurunkan hasil panen. Selanjutnya Pratiwi \& Salim (2013) menambahkan bahwa aliran permukaan dan erosi dapat diatasi dengan penerapan teknik konservasi tanah dan air, seperti pembuatan rorak (saluran) yang memotong lereng. Selain itu, lahan yang telah terdegradasi memerlukan bahan organik yang lebih tinggi, seperti mulsa dan pupuk kandang yang berfungsi untuk memperbaiki fisik tanah dan penambahan unsur hara sehingga tingkat kesuburan lahan meningkat (Aziz, Hazra, Salma, \& Nursyamsi (2016).

Hasil penelitian menunjukkan jika dibandingkan dengan plot kontrol, maka perlakuan mulsa vertikal pada kombinasi tanaman S. johorensis dan G. gnemon dapat menurunkan aliran permukaan dan erosi masing-masing sebesar $61,74 \%$ dan $57,14 \%$ dan pada perlakuan S. johorensis dan P. speciosa dapat menurunkan aliran permukaan dan erosi masing-masing sebesar $81,39 \%$ dan $17,64 \%$ (Tabel 1). Hal ini terjadi juga di kebun sawit tanpa mulsa vertikal, sedimentasi yang terjadi sebesar $15,3 \mathrm{~kg} / \mathrm{ha}$, sedangkan pada perlakuan mulsa vertikal sedimentasi menjadi 8,3 $\mathrm{kg} / \mathrm{ha}$ (Murtilaksono, Sutarta, Siregar, Darmosarkoro, \& Hidayat (2008). Sementara aliran permukaan yang terjadi pada plot kontrol sebesar $508,3 \mathrm{~mm} / \mathrm{ha} /$ tahun dan pada plot dengan perlakuan 
mulsa vertikal sebesar $12,8 \mathrm{~mm} / \mathrm{ha} / \mathrm{tahun}$. Menurut Rauf (2008), perlakuan mulsa vertikal pada pertanian di lahan miring, dapat menurunkan erosi dan aliran permukaan yang terjadi masing-masing 6,10 ton/ha/tahun dan $8,37 \%$ terhadap curah hujan; sedangkan pada mulsa konvensional (ditebarkan di permukaan tanah) menunjukkan erosi dan aliran permukaan masing-masing sebesar 10,95 ton/ha/tahun dan $14,18 \%$ terhadap curah hujan.

Jika dibandingkan antara perlakuan A dan $\mathrm{C}$ dimana kedua perlakuan menggunakan mulsa vertikal tetapi dengan kombinasi jenis yang berbeda, terlihat hasilnya bahwa perlakuan A meskipun aliran permukaan tinggi, namun erosinya rendah. Pada perlakuan $\mathrm{C}$ aliran permu-kaannya lebih rendah, tetapi erosinya lebih tinggi. Hal ini karena model tajuk jenis G. gnemon berbeda dengan P. speciosa. Pada G. gnemon susunan daunnya tunggal dan bentuk tajuk silindris dengan kerapatan tajuk rapat, sementara P. speciosa susunan daun majemuk dan bentuk tajuk payung tetapi kerapatan tajuk jarang (Mahendra, 2009). Pada perlakuan A, air hujan yang turun sebagian kecil langsung ke tanah, sebagian besar ditangkap tajuk dan dialirkan sebagai aliran batang (stemflow). Dalam kondisi ini, tenaga merusak air menjadi sangat kecil sehingga tidak merusak struktur tanah. Pada perlakuan $\mathrm{C}$, air hujan sebagian besar akan jatuh ke tanah, dan butir-butir air hujannya berpotensi merusak struktur tanah sehingga partikel tanah menjadi lepas dan mudah terbawa oleh aliran sebagai erosi percik (splash erosion) (Angulo-Martinez, Begueria, \& Kysely, 2016; Begueria, Angulo-Martinez, \& Navas, 2015; Ghahramani, Ishikawa, Gomi, Shiraki, \& Miyata, 2011). Dengan demikian, meskipun aliran permukaan pada perlakuan A lebih besar, namun karena aliran permukaan tersebut berasal dari aliran batang, maka daya erosinya rendah.
Sementara pada perlakuan C, meskipun aliran permukaannya lebih rendah daripada A tetap saja erosinya lebih tinggi karena ada faktor splash erosion.

Hasil penelitian lainnya menunjukkan bahwa kehilangan unsur hara $(\mathrm{N}, \mathrm{P}, \mathrm{K}, \mathrm{Ca}$, $\mathrm{Mg}$, Na) melalui erosi lebih kecil dibandingkan kehilangan unsur hara melalui aliran permukaan. Hal ini terjadi karena unsur-unsur hara terlarut di dalam air dimana jumlah massa airnya per satuan waktu dan satuan luas lebih besar dibandingkan dengan massa partikel erosi. Dengan demikian, unsur hara yang hilang melalui aliran permukaan lebih besar daripada melalui erosi. Secara keseluruhan dari hasil penelitian ini, terdapat kecenderungan bahwa kehilangan unsur hara untuk semua unsur $(\mathrm{N}, \mathrm{P}, \mathrm{K}, \mathrm{Ca}, \mathrm{Mg}$, $\mathrm{Na}$ ) lebih besar terjadi pada lahan tanpa perlakuan mulsa vertikal.

Teknik Mulsa Vertikal memiliki kelebihan dibanding dengan teknik mulsa biasa. Karena dengan teknik mulsa vertikal, sisa-sisa tanaman dimasukkan ke dalam saluran dan dapat berfungsi selain sebagai sumber unsur hara, juga dapat menyerap dan memegang massa air dalam jumlah besar sehingga dapat menyimpan air dalam tanah (McNear Jr, 2013). Saluran dalam mulsa vertikal berfungsi antara lain dapat meningkatkan infiltrasi sehingga mengu-rangi laju aliran permukaan dan erosi. Disamping itu, saluran dapat berfungsi sebagai tempat terendapkannya partikel-partikel tanah yang terbawa oleh aliran dari bidang di atas saluran. Jika tidak ada saluran yang berisi mulsa tersebut, maka partikelpartikel tanah akan hilang bersama aliran permukaan dan erosi. Akibatnya unsur hara di dalam tanah akan hilang. Oleh karena itu, pemakaian mulsa akan sangat membantu dalam meminimalkan kehilangan unsur hara, bahkan jika telah terdekomposisi, maka akan meningkatkan jumlah hara kembali. Menurut Akbar (2016) bahwa mulsa yang lambat mengurai akan lebih lama melembabkan 
tanah dan menstabilkan suhu sehingga mendorong mikroba-mikroba tanah membantu proses dekomposisi di atas permukaan tanah. Pemberian mulsa vertikal ditambah pupuk kandang yang dibenamkan dapat memperbaiki Corganik dan N-total (Marbun, Rauf, \& Hanum, 2016). Hasil penelitiannya menunjukkan bahwa perlakuan mulsa vertikal dapat meningkatkan pertambahan tinggi bibit tebu sebesar $21,9 \%$, jumlah tanaman per rumpun $6,8 \%$, bobot basah $68,28 \%$ dan bobot kering 41,96\% dibandingkan dengan pemberian mulsa horizontal. Hal ini menunjukkan bahwa perlakuan mulsa vertikal jika dibandingkan dengan penerapan mulsa horizontal dan tanpa pemberian mulsa cukup efektif dalam mengendalikan erosi dan aliran permukaan serta kehilangan unsur hara.

Kehilangan unsur hara baik melalui aliran permukaan maupun melalui erosi akan mempengaruhi pertumbuhan tanaman, karena keterbatasan konsentrasi unsur hara. Tabel 4 menunjukkan bahwa pertumbuhan tinggi dan diameter tanaman S. johorensis pada perlakuan A lebih besar daripada perlakuan C. Hal ini karena besaran erosi dan kehilangan unsur hara akibat erosi di perlakuan A lebih kecil daripada perlakuan C. Pertumbuhan pohon dipengaruhi oleh banyak faktor, seperti kerapatan tegakan, temperatur, jumlah dan distribusi curah hujan sepanjang tahun, kelembaban udara, komposisi kimia tanah, dan kandungan hara (Soekotjo, 2009; Mindawati, 2016). Pohon sebagai komponen penyusun ekosistem tidak dapat terlepas dari komponen ekosistem lainnya, saling berpengaruh dan terkait satu sama lain secara simultan dan akan mempengaruhi pertumbuhan pohon (Mindawati, 2011). Secara garis besar faktor-faktor yang mempengaruhi pertum-buhan pohon dapat dikelompokkan dalam tiga kelompok, yaitu faktor genetik, faktor lingkungan, dan tindakan silvikultur. Faktor lingkungan yang berhubungan dengan pertumbuhan pohon salah satunya adalah kondisi tanah (Aziz., Hazra, Salma \& Nursyamsi, 2016). Tanah merupakan faktor edafis yang penting untuk pertumbuhan tanaman karena tanah merupakan perantara penyedia faktorfaktor suhu, udara, air dan unsur-unsur hara yang mempengaruhi pertumbuhan tanaman. Unsur hara makro $(\mathrm{N}, \mathrm{P}, \mathrm{K}, \mathrm{Ca}$, dan $\mathrm{Mg}$ ) merupakan unsur kimia yang dapat dijadikan sebagai indikator kesuburan suatu tapak karena merupakan unsur hara yang secara fundamental dibutuhkan dan diserap tanaman untuk proses pertumbuhan dan proses metabolisme (Mindawati, 2012). Saat ini kondisi lahan kehutanan sebagian besar sudah terdegradasi sehingga teknologi pemupukan sudah menjadi keharusan agar hasil optimal. Dalam hal ini, pemupukan dengan menggunakan pupuk organik/ hayati baik sebagai katalisator proses dekomposisi bahan organik, maupun sebagai pelarut hara yang terkandung dalam tanah atau bahan organik menjadi sangat penting (Husnain, Nursyamsi, \& Syakir, 2016).

Hasil penelitian menunjukkan bahwa pola tanam campuran antara S. johorensis dengan G. gnemon maupun dengan $\mathrm{P}$. speciosa yang menerapkan penggunaan mulsa vertikal dapat mengurangi dan menekan unsur hara yang hilang sekitar $300 \%$ (Tabel 3), artinya kesuburan tanah di lahan akan terjaga dan akan bertambah seiring dengan terjadinya proses dekomposisi dari mulsa tersebut. Hal ini mempengaruhi pertumbuhan tinggi dan diameter ketiga tanaman yang diusahakan. Sampai umur 3 tahun, tanaman S. johorensis telah mencapai tinggi dan diameter sebesar 120,31 cm dan 13,13 $\mathrm{mm}$, sedangkan tanaman G. gnemon mencapai $88,89 \mathrm{~cm}$ dan $9,78 \mathrm{~mm}$; dan tanaman P. speciosa telah mencapai tinggi $111,43 \mathrm{~cm}$ dan diameter $10,30 \mathrm{~mm}$, lebih besar dibanding tanpa pemberian mulsa vertikal.

Produktivitas suatu ekosistem dapat dipertahankan jika tanah dapat melakukan 
fungsinya secara optimal karena tanah merupakan salah satu faktor lingkungan yang mempengaruhi pertumbuhan tanaman dan dapat dimanipulasi melalui teknik silvikultur (Mindawati, 2016). Salah satu manipulasi lingkungan tersebut antara lain pemberian mulsa vertikal yang dalam penelitian ini telah terbukti dapat memperbaiki kesuburan tanah hutan sehingga meningkatkan pertumbuhan tanaman. Namun demikian, dekomposisi mulsa sangat tergantung pada aktivitas dekomposer dalam proses mineralisasinya agar menjadi bentuk unsur hara yang sudah terurai dan mudah diserap tanaman.

Berdasarkan hasil penelitian ini dapat disimpulkan, bahwa penerapan mulsa vertikal pada lahan terdegradasi sangat efektif dalam mengurangi laju aliran permukaan, erosi, dan kehilangan unsur hara serta dapat meningkatkan pertumbuhan tinggi dan diameter tanaman yang diusahakan, baik tanaman kehutanan S. johorensis maupun tanaman pertanian G. gnemon dan P. speciosa. Diharapkan jika tanaman dapat tumbuh baik, maka produktivitas tanaman juga meningkat. Konsekuensi dari penerapan teknik mulsa vertikal adalah diperlukan tambahan biaya untuk pembuatan mulsa vertikal terutama untuk penggalian saluran mulsa vertikal. Jarak antar saluran perlu diatur dengan mempertimbangkan aspek ekonomis. Namun demikian dari segi ekologi, penerapan teknik ini diharapkan dapat memulihkan dan meningkatkan produktivitas lahan.

Dalam merehabilitasi lahan terdegradasi, lebih baik dengan penerapan pola tanam campuran. Menurut Wahyudi (2011) penanaman kombinasi beberapa jenis unggulan akan lebih resisten terhadap serangan hama dan penyakit, lebih fleksibel dalam memenuhi permintaan pasar, dan tercipta keunggulan komparatif. Pola tanam campuran seperti pada penelitian ini, selain menjaga kelestarian lingkungan juga meningkatkan pendapatan masyarakat sekitar hutan.
Berdasarkan hasil perhitungan biaya penanaman jenis pohon dengan menerapkan teknik mulsa vertikal pada lahan terdegradasi, biaya yang harus dikeluarkan per hektar sebesar Rp. 5.700 .000 (di luar biaya penyiapan lahan) dan mudah dalam penerapannya. Oleh karena itu, dalam membangun hutan tanaman di lahan terdegradasi atau di lahan kritis penggunaan mulsa vertikal sangat bermanfaat baik dari segi ekonomi maupun dari segi ekologi.

\section{KESIMPULAN DAN SARAN}

\section{A. Kesimpulan}

Teknik konservasi tanah dan air dengan mulsa vertikal yang diterapkan pada pola tanam campuran antara $\mathrm{S}$. johorensis dan G. gnemon maupun campuran antara $\mathrm{S}$. johorensis dan $\mathrm{P}$. speciosa efektif dalam mengurangi laju aliran permukaan dan erosi serta dapat meningkatkan pertumbuhan tinggi dan diameter sampai pengamatan tanaman umur 3 tahun di lapangan. Pada pola tanam kombinasi antara S. johorensis dan G. gnemon, mulsa vertikal dapat menurunkan aliran permukaan dan erosi masing-masing $61,74 \%$ dan $57,14 \%$; dan pada pola tanam kombinasi S. johorensis dan P. speciosa, dapat menurunkan laju aliran permukaan dan erosi sebesar $81,39 \%$ dan $17,64 \%$. Penggunaan mulsa vertikal dapat mengurangi kehilangan unsur hara $(\mathrm{N}, \mathrm{P}, \mathrm{K}, \mathrm{Ca}, \mathrm{Mg}, \mathrm{Na})$ baik melalui erosi maupun melalui aliran permukaan. Selain itu, adanya mulsa vertikal dapat meningkatkan pertumbuhan tinggi dan diameter ketiga jenis yaitu $\mathrm{S}$. johorensis, G. gnemon dan P. speciosa yang diusahakan. Konsekuensinya adalah diperlukan tambahan biaya untuk menerapkan teknik ini.

\section{B. Saran}

Pada kawasan hutan yang topografinya curam sebaiknya kegiatan penanaman (rehabilitasi) menggunakan 
mulsa vertikal dengan pola tanam campuran.

\section{UCAPAN TERIMA KASIH}

Penulis menyampaikan terima kasih kepada semua pihak yang telah membantu dalam pelaksanaan penelitian ini, terutama kepada Bapak Atep Dono sebagai pengelola Hutan Penelitian Carita dan kepada para teknisi yang telah membantu dalam pengambilan data lapangan ini.

\section{DAFTAR PUSTAKA}

Akbar, A. (2016). Pengaruh penutupan mulsa organik terhadap perkenbangan gulma hutan tanaman nyawai. Jurnal Penelitian Hutan Tanaman, 13(2), 95-103.

Angulo-Martinez, M., Begueria, S., \& Kysely, J. (2016). Use of disdrometer data to evaluate the relationship of rainfall kinetic energy and intensity (KE-I). Science of The Total Environment, 568, 83-94.

Aziz, A., Hazra, M.F., Salma, S., \& Nursyamsi, D. (2016). Soil chemical charakteristics of organic and conventional agricultur. Jurnal of Tropical Soil, 21(1), 19-25.

Begueria, S., Angulo-Martinez, M., \& Navas, A. (2015). Detachment of Soil Organic Carbon by rainfall spalsh: Experimental assessment on three agricultural soil of Spain. Geoderma, 245-246, 21-30.

Ghahramani, A., Ishikawa,Y., Gomi, T., Shiraki, K., \& Miyata, S. (2011). Effect of ground cover on splash and sheetwash erosion over a step forested hillslope: A plot scale study. Catena, 85, 34-47.

Harijanto, M., Sinukaban, N., Tarigan, S.D., \& Haridjaja, O. (2016). Evaluasi kemampuan lahan untuk arahan penggunaan lahan di DAS
Lawo, Sulawesi Selatan. Jurnal Penelitian Kehutanan Wallacea, 5(11), 1-11.

Husnain, Nursyamsi, D., \& Syakir, M. (2016). Teknologi pemupukan mendukung jarwo super. Jurnal Sumber Daya Lahan, 10(1), 1-10.

Mahendra, F. (2009). Agrofestri: Sistem Agroforestri dan Aplikasinya. Graha Ilmu. Yogyakarta.

McNear Jr, D.H. (2013). The rhizosphereroot,soil and everything in between. Natural Education Knowledge, 4(3), 1.

Marbun, A., Rauf, A., \& Hanum, C. (2016). Teknik mulsa vertikal pada budidaya tebu (Saccharum officinarum L.) ratoon satu. Jurnal Pertanian Tropik, 3(1), 82-91.

Mindawati, N. (2011). Kajian kualitas tapak hutan tanaman industri hibrid Eucalytus urograndis sebagai bahan baku industri pulp dalam pengelolaan hutan lestari. [Disertasi] Sekolah Pascasarjana. Institut Pertanian Bogor.

Mindawati, N. (2012). Penerapan Silvikultur Intensif Ramah Lingkungan dalam Pengelolaan Hutan Tanaman Industri. Badan Penelitian dan Pengembangan Kehutanan. Kementerian Kehutanan.

Mindawati, N. (2016). Pentingnya penerapan teknik silvikultur dan bioteknologi untuk meningkatkan produktivitas hutan. Mitra Hutan Tanaman 11(2), 19-22.

Mindawati, N. (2016). Pengembangan inovasi bidang silvikultur dalam pengelolan hutan : Peluang dan tantangan. Mittra Hutan Tanaman, 11(1), 23-29.

Murniati. (2012). Teknik pengayaan pada lahan garapan masyarakat di hutan penelitian Carita. Jurnal Penelitian Hutan dan Konservasi Alam, 9(1), 69-83.

Murtilaksono, K., Sutarta, E.S., Siregar, H.H., Darmosarkoro, W., \& Hidayat, 
Y. (2008). Penerapan teknik konservasi tanah dan air dalam upaya penekanan aliran permukaan dan erosi di kebun kelapa sawit. Dalam: Prosiding Seminar dan Kongres Nasional MKTI VI, 17-18 Desember 2007, 165-171.

Pratiwi. (2007). Laju aliran permukaan dan erosi di berbagai hutan tanaman dan beberapa alternatif upaya perbaikannya. Jurnal Penelitian Hutan dan Konservasi Alam, 4(3), 267-276.

Pratiwi, \& Narendra, B.H. (2012). Pengaruh penerapan teknik konservasi tanah terhadap pertumbuhan pertanaman mahoni (Swietenia macrophylla King.) di hutan penelitian Carita, Jawa Barat. Jurnal Penelitian Hutan dan Konservasi Alam, 9(2), 39-150.

Pratiwi, \& Salim, A.G. (2013). Aplikasi konservasi tanah dengan sistem rorak. Jurnal Penelitian Hutan dan
Konservasi Alam, 10(3), 273-282.

Pusat Penelitian dan Pengembangan Hutan. (2015). Profil KHDTK Carita. Pusat Penelitian dan Pengembangan Hutan.

Rauf, A. (2008). Pengendalian erosi dan limpasan permukaan menggunakan teknik mulsa vertikal pada budidaya jeruk manis di lahan miring. Jurnal Agrista, 12(1), 1-9.

Soekotjo. (2009). Teknik Silvikultur Intensif. Gadjah Mada Univercity Press.

Wahyudi, A. (2011). Pertumbuhan tanaman dan tegakan tinggal pada tebang pilih tanam indonesia intensif: studi kasus di Areal Kerja IUPHHK-HA PT Gunung Meranti, Provinsi Kalimantan Tengah. [Disertasi]. Sekolah Pascasarjana, Institut Pertanian Bogor. 